\title{
Adaptation of Beans (Phaseolus vulgaris L.) to Low Phosphorus Availability
}

\author{
Jonathan P. Lynch ${ }^{1}$ \\ Department of Horticulture, The Pennsylvania State University, University Park, PA 16802 \\ Stephen E. Beebe \\ Bean Program, International Center for Tropical Agriculture, Apartado Aéveo 6713, Cali, Colombia
}

\begin{abstract}
Phosphorus availability in native soils is seldom adequate for optimal plant growth. Of the macronutrients, $\mathrm{K}, \mathrm{Ca}, \mathrm{Mg}$, and $\mathrm{S}$ are not uncommon in the earth's crust and in fresh water (Epstein, 1972); $\mathrm{N}$ is abundant in the atmosphere and is present in most soil solutions in millimolar concentrations. In contrast, $\mathrm{P}$ is present in soil solution and fresh water in only micromolar concentrations (Rendig and Taylor, 1989), in large part because $P$ is commonly bound to many soil constituents that make it unavailable or only sparingly available to plants (Sample et al., 1980). An additional problem is that the $\mathrm{P}$ cycle in most terrestrial ecosystems is open-ended and tends toward depletion, unlike the $\mathrm{N}$ cycle, in which atmospheric pools provide continual inputs to soil pools (Stevenson, 1986). Phosphorus availability is generally low in volcanic soils (Andosols) with high allophane content, weathered mineral soils (Oxisols, Ultisols, some Alfisols) characterized by $\mathrm{Fe}$ and $\mathrm{Al}$ oxide chemistry, and coniferous forest soils (Spodosols). Taken together, these soils support most of the earth's vegetation and much of its human population.
\end{abstract}

Low $\mathrm{P}$ availability is a primary constraint to agricultural productivity in many low-input systems in developing countries and can be a significant cost of production in high-input systems, especially where soil chemical conditions "fix" applied fertilizer into less available forms over time so that continual high inputs are needed. In high-value crops in the United States, the costs of P fertilizer are typically a small percentage of overall production costs, but in the aggregate, $\mathrm{P}$ fertilizers cost U.S. farmers close to 10 billion dollars per year (Netzer, 1987). Over the next century or two, the economics of $\mathrm{P}$ fertilization will be changed by the exhaustion of high-grade ore deposits (Cathcart, 1980). In this sense also, $P$ differs from $N$ in that the Haber process continually replenishes a vast pool of atmospheric $\mathrm{N}$ that can be converted to fertilizer, whereas high-grade $\mathrm{P}$ ore deposits are of limited size and distribution and represent an essentially nonrenewable resource. Perhaps the most important economic and environmental concern over P fertilizer in the United States pertains to its role as a pollutant in surface waters from agricultural runoff.

Understanding the nature of plant adaptation to limited $P$ availability has relevance to the low-input agriculture that still predominates over much of the globe, and to high-input systems, where more Pefficient crops and cropping systems would require less fertilizer and cause less environmental pollution. The focus of this article will be recent approaches taken to understand the adaptation of bean to low $\mathrm{P}$ availability.

\section{Genetic variation in bean yields in low-P tropical soils}

In the tropics, several researchers have demonstrated genetic differences in tolerance to low-P conditions, i.e., the ability to produce economic yields with suboptimal $\mathrm{P}$ availability. Work of this nature

Received for publication 17 Mar. 1995. Accepted for publication 6 Apr. 1995. We thank the many collaborators, students, and mentors, including André Läuchli and Emanuel Epstein, Univ. of California, Davis; Yan Xiaolong, South China Agricultural Univ.; Sieglinde Snapp, Rockefeller Foundation; and Andrei Jablokow, Roger Koide, Robert Davis, Kai Nielsen, Amy Bonser, and Jae Pyo Han, Pennsylvania State Univ., who contributed to the research summarized. This research was supported in part by U.S. Dept. of Agriculture/ National Research Initiative grant 94371000311 and National Science Foundation grant BIR-9220330 to J.P.L. The cost of publishing this paper was defrayed in part by the payment of page charges. Under postal regulations, this paper therefore must be hereby marked advertisement solely to indicate this fact.

${ }^{1}$ To whom reprint requests should be addressed. has been carried out in Colombia (Thung, 1990; Youngdahl, 1990), Brazil [Salinas, 1978; International Center for Tropical Agriculture (CIAT), unpublished data], Costa Rica (Corella, unpublished data), and Nicaragua (Tapia, 1987). In at least one case, recommendations for $\mathrm{P}$ applications were tailored cultivar by cultivar, from 0 to $42 \mathrm{~kg} \mathrm{P} /$ ha, depending on the $\mathrm{P}$ requirements of the specific genotype. The Brazilian cultivar Carioca is broadly adapted to low-P conditions, and is extremely responsive to added $\mathrm{P}$ (Thung, 1990). These traits undoubtedly contribute to the fact that 'Carioca' is the most widely grown cultivar in Brazil (Janssen et al., 1992). In Rwanda, a climbing bean from Mexico, G2333, has gained great popularity among small farmers and is doubling yields over traditional bush cultivars in the central plateau. Like 'Carioca', G2333 is tolerant to low P and responsive to added $\mathrm{P}$ (CIAT, unpublished data). These examples are suggestive of the importance of the genotypic response to $\mathrm{P}$ in agronomic performance and in farmer acceptance. They also demonstrate that low-P tolerance is not incompatible with high yield potential. Some traits are probably favorable under high and low fertility, such as an efficient root system. However, in no case has any cultivar in use in the tropics or in the temperate zone been bred specifically for low-P tolerance. Selection of tolerant cultivars has been among germplasm accessions or advanced-generation finished lines and, in some cases, has been a totally fortuitous result of testing under farmers' conditions. In fact, one documented, extensive attempt to breed for improved low-P tolerance failed to recover any genotypes superior to the tolerant controls (Singh et al., 1989). This failure was attributed to insufficient genetic variability employed within the breeding program.

\section{Evolution of bean adaptation to low $P$ in diverse environments}

We have placed high priority in recent years on broadening the genetic base of low-P tolerance. As a by-product of our investigation of low-P response of a broader sample of bean germplasm, we have observed that the wild ancestor of the cultivated common bean is particularly sensitive to $\mathrm{P}$ deficiency and shows little adaptation to low-P conditions, although wild beans from the Andean region are better than those from Mesoamerica (Singh, Gutierrez, Molina, Urrea, and Gepts, unpublished data). The poor performance of wild beans under low $\mathrm{P}$ is pertinent to efforts to improve low-P tolerance, especially because it suggests that the tolerance that has been observed in the cultivated common bean probably evolved after plant domestication. Evolution of tolerance mechanisms could have occurred as early cultivars were moved out of their original environment and into "foreign," P-deficient environments. This pattern offers the possibility that differing genes may have been selected in various environments, resulting in genetic diversity that could be used in breeding programs, if identified. This possibility may exist within and between gene pools.

We studied the relationship between geographic origin and response to low $\mathrm{P}$ in a selection of 364 genotypes drawn from CIAT's gene bank (Beebe, Lynch, J. Tohme, and I. Ochoa, unpublished data). These genotypes originated in 21 countries and represented a broad sample of primary-center germplasm and a small number of secondarycenter accessions, principally from Africa. Some tendencies were in agreement with the types of soils in the regions where groups of accessions originated. For example, materials from Chiapas, a state in southern Mexico where soils are severely acidic and $\mathrm{P}$ deficient, were especially promising in low-P soils (Table 1). Materials from some other regions were especially poor. In a preliminary yield trial under $\mathrm{P}$ stress, Mesoamerican accessions from Chiapas yielded as much as 
Table 1. Yields of some bean germplasm accessions that were superior to their respective controls under $\mathrm{P}$ stress in four independent trials. Each mean is the average yield of three replications in each of four field trials for the Peruvian bush genotypes, in each of three field trials for the climbing genotypes, and in one field trial for the Mexican bush genotypes.

\begin{tabular}{|c|c|c|c|c|c|}
\hline \multirow[b]{2}{*}{ CIAT accession } & \multirow[b]{2}{*}{ Origin } & \multicolumn{4}{|c|}{ Grain yield $\left({\left.\mathrm{kg} \cdot h a^{-1}\right)}^{-1}\right.$} \\
\hline & & $\begin{array}{c}\text { Low } \\
\mathrm{P}\end{array}$ & $\begin{array}{l}\text { Percent } \\
\text { control }\end{array}$ & $\begin{array}{c}\text { High } \\
\text { P }\end{array}$ & $\begin{array}{l}\text { Percent } \\
\text { control }\end{array}$ \\
\hline \multicolumn{6}{|c|}{ Bush indeterminate } \\
\hline G 1937 & Mexico & 1506 & 181 & 3749 & 108 \\
\hline G 3513 & Mexico & 1249 & 150 & 2704 & 78 \\
\hline G 2444 & Mexico & 1171 & 141 & 2426 & 70 \\
\hline G 2351 & Mexico & 1130 & 136 & 3616 & 104 \\
\hline G 3593 & Mexico & 1133 & 136 & 3028 & 87 \\
\hline G 16274 & Mexico & 1118 & 134 & 2907 & 84 \\
\hline G 19833 & Peru & 1382 & 123 & 2905 & 109 \\
\hline G 19839 & Peru & 1239 & 111 & 3003 & 113 \\
\hline \multicolumn{6}{|l|}{ Climbing } \\
\hline G 11400 & Mexico & 1171 & 132 & 4541 & 94 \\
\hline G 11049 & Mexico & 1145 & 129 & 5433 & 113 \\
\hline G 3456 & Mexico & 1137 & 129 & 4899 & 101 \\
\hline G 2829 & Mexico & 1103 & 125 & 5321 & 111 \\
\hline G 11702 & Peru & 1807 & 172 & 3524 & 123 \\
\hline G 7300 & Peru & 1566 & 149 & 2793 & 98 \\
\hline G 12105 & Peru & 1539 & 147 & 3302 & 116 \\
\hline G 16106 & Peru & 1502 & 143 & 2208 & 77 \\
\hline
\end{tabular}

$1506 \mathrm{~kg} \cdot \mathrm{ha}^{-1}$, or $81 \%$ more than the 'Carioca' control (Table 1). In the Andean zone, a valuable pocket of genetic diversity was discovered in the Amazonas province of Peru. The Peruvian bush accession G19833 averaged 23\% more yield than 'Carioca' over four seasons (Table 1). G19833 was compared with 'Carioca' at several levels of P fertilization. G19833 yielded almost twice that of 'Carioca' at the lowest P level. Other accessions from the Amazonas province also have performed very well. Some climbing beans from Peru were selected with apparent success (Table 1), although these typically mature much later than Mesoamerican climbers; thus, part of their apparent low-P tolerance may be due to their longer season. Some of the accessions do not respond to added $\mathrm{P}$ as well as the G2333 control. Mexican climbing beans from Jalisco and Michoacan states also were extensively screened for tolerance. A group of four elite climbing types have been identified; these yield from $25 \%$ to $32 \%$ more than G2333, the tolerant control, under low-P stress but maintain high yield, similar to G2333, without stress (Table 1).

As a result of several years' work, Singh et al. (1991) identified elite genotypes for low-P tolerance in contrasting gene pools and races of bean. These genotypes include Andean bush types from Peru (race N); Mesoamerican bush types from Chiapas (race M); Mesoamerican climbing types from west-central Mexico (race J); and types that evidently are intergene pool recombinants from Colombia. These genotypes are undoubtedly very diverse genetically with respect to their morphoagronomic traits and their evolutionary origins. It is likely that the genetic diversity reflects diversity of physiological mechanisms of $\mathrm{P}$ efficiency that can be recombined to improve upon efficiency even further. This aim would be greatly facilitated by identifying such mechanisms.

\section{Progress and problems in breeding P-efficient beans}

The first attempts to genetically improve bean for P efficiency were based on genotypes identified by Whiteaker et al. (1976) in a laboratory screening using a nutrient-depletion hydroponic system. The criterion used to discriminate genotypes was dry weight production per unit of available P. A 1.7-fold difference was found among genotypes for this variable. The same authors suggested that genes for $\mathrm{P}$ efficiency might present dominant or overdominant gene action, depending on the hybrid combination. More detailed genetic studies revealed complex inheritance of total plant dry weight under P stress with additive, dominance, and several types of epistatic gene effects, again depending on the hybrid combination (Fawole et al., 1982a). Root dry weight under $\mathrm{P}$ stress in a laboratory evaluation presented dominance and additive effects, in that order of importance (Fawole et al., 1982b). Schettini et al. (1987) successfully employed one accession of exotic germplasm, PI206002, a snap bean from Sweden, in a breeding program to improve the dry bean cultivar Sanilac. The $F_{1}$ of the two materials was backcrossed twice to 'Sanilac', and progenies were self-pollinated for several generations to produce a set of inbredbackcrossed progenies. Lines were obtained that were superior to 'Sanilac' in grain yield in the field and in dry matter accumulation in laboratory and field tests, and that were almost identical in morphology and phenology. Evidence suggested that the trait transferred to 'Sanilac' influenced $\mathrm{P}$ acquisition.

We have used a breeding methodology based on bulked population yield testing and early generation yield testing of families, similar to that suggested by Boerma and Cooper (1975), with good results. We used a similar method in a breeding project in Costa Rica to select among and within segregating populations involving parents identified in the first stages of germplasm evaluation. One source of low-P tolerance was a Mexican climber, a second was a collection from Peru. Progeny were tested in two contrasting sites, in an Ultisol in Perez Zeledon, and in an Andosol in Fraijanes. From the populations derived from these sources, lines were developed that in several trials outyielded the local low-P control.

However, in the breeding nurseries and in yield evaluation of germplasm over seasons, genotype $\times$ environment interaction has had a large effect on P-tolerance differences. Season-to-season variation is normal even in unstressed plots of agronomic yield trials, but in analysis of variance of stressed and unstressed plots over seasons, we find genotype $\times$ season, genotype $\times \mathrm{P}$ level, and genotype $\times$ season $\times$ $\mathrm{P}$ level interactions. This latter interaction implies inconsistent behavior of some genotypes over seasons in their response to low P, and complicates the identification and selection of tolerance. This finding underscores the difficulty of relying on yield trials as a criterion of selection for a breeding program. Yield trials are not only costly to run, but are not highly reliable. It would be far more reliable, and preferable, to identify a mechanism of tolerance and to select for the mechanism per se, either directly or indirectly through molecular markers.

\section{Potential of molecular markers for selection of $\mathbf{P}$ efficiency}

One of the most dramatic and far-reaching advances in biology in recent years has been the development of simple techniques to analyze and manipulate DNA. Two of these techniques, restriction fragment length polymorphisms (RFLPs) and random amplified polymorphic DNA (RAPDs), have received particular attention from breeders and geneticists as potential selection tools in breeding programs. In particular, RAPDs have attracted interest because most researchers find them to be more economical and quicker to use than RFLPs. The RAPD technique employs short oligonucleotide primers to amplify segments of genomic DNA (Williams and Kubelik, 1990). Combined with bulk segregant analysis (Michelmore et al., 1991), RAPDs offer the advantage of quickly screening many primers to detect linked markers. RAPD markers linked to useful genes have been identified in tomato (Lycopersicon esculentum Mill.) (Martin et al., 1991), lettuce (Lactuca sativa L.) (Paran and Michelmore, 1992), and common bean (Miklas et al., 1993).

Molecular markers would be especially useful for selecting genes for P efficiency, considering the difficulties cited previously of using yield trials under field conditions to identify P-efficient genotypes. Phosphorus efficiency is a typical quantitative trait that is subject to great environmental variability. Theoretically, molecular markers may overcome these difficulties and aid selection (Tanksley et al., 1989). Although computer programs exist to assist in tagging quantitative trait loci (QTLs) where mapped markers are available, molecular markers for QTLs may be difficult to identify due to problems in obtaining reliable phenotypic data. Inconsistency in phenotypic data over sites or seasons will produce variable results with respect to molecular markers. However, if a seemingly complex character, such as $\mathrm{P}$ efficiency, could be resolved into physiological mechanisms governed by discrete traits that can be easily recognized, then these traits could be tagged with molecular markers more reliably than $\mathrm{P}$ efficiency could be measured as a quantitative trait by yield trials. 


\section{Possible physiological mechanisms of $\mathbf{P}$ efficiency}

Nutrient efficiency has been defined many ways in diverse contexts (Clark, 1990). Most definitions share the concept that efficiency can be expressed as the ability of a system to convert inputs to outputs. In the case of $\mathrm{P}$ efficiency, we express this as growth and yield in relation to available $\mathrm{P}$ from soil pools or soil amendments, which incorporates the ability to yield at low $\mathrm{P}$ with responsiveness to fertilizer inputs. Theoretically, many distinct physiological traits could contribute to enhanced $\mathrm{P}$ efficiency, which could eventually be recombined and incorporated into P-efficient genotypes.

In considering possible mechanisms of $\mathrm{P}$ efficiency, we can distinguish between traits conferring phosphorus acquisition efficiency, or superior ability to acquire $\mathrm{P}$ from the environment, from those conferring phosphorus utilization efficiency, or superior ability to convert $\mathrm{P}$ into growth and yield once it has been acquired. Several possible mechanisms of $\mathrm{P}$ utilization efficiency are:

Reduced tissue $P$ requirement would manifest itself in lower tissue $\mathrm{P}$ concentrations. In extensive experimentation to date, we have not found substantial genetic variation for tissue $\mathrm{P}$ requirements under steady-state $\mathrm{P}$ stress that are positively related to genotype efficiency (Yan, 1992; Lynch and Beebe, unpublished data).

Phenology may affect $\mathrm{P}$ use efficiency by extending the time available for physiological use, such as in photosynthesis, of plant $P$ resources. In replicated studies of beans of contrasting phenologies (days to maturity) in tropical field environments, longer-season genotypes had some advantage over shortduration genotypes in low-P environments (unpublished data). This trait would have limited utility in bean cropping systems, however, because the bean growing season is usually restricted by rainfall distribution or by the requirements of other crops, such as maize (Zea mays L.), in the rotation or intercrop system. We also have observed significant variation in $\mathrm{P}$ efficiency between genotypes with similar intervals to maturity (Yan, 1992), which could not be explained on the basis of phenology.

Seed $P$ reserves may be important in seedling establishment in low-P soil. Seed P storage may vary between large-seeded genotypes of the Andean gene pool and small-seeded Mesoamerican genotypes by a factor of 4 (Sadeghian, 1991). As with phenology, differences in $\mathrm{P}$ efficiency between highly contrasting seed classes is of limited agronomic utility, since seed classes are associated with specific consumer preferences that vary between nations and cultures. In any case, our studies of the effect of seed $\mathrm{P}$ reserves on seedling establishment of bean genotypes in low-P soil showed that effects were limited to early seedling growth and could not account for genetic differences in yield under P stress (Sadeghian, 1991). We also have observed significant genetic variation in $\mathrm{P}$ efficiency between genotypes of the same seed size, and although largeseeded materials tend to be P-efficient, this may be due to associated influences of cell size rather than $P$ reserves per se (Yan, 1992).

We therefore hypothesize that existing genetic variation for $\mathrm{P}$ efficiency in bean germplasm, especially variation that is agronomically useful, is largely due to variation in $\mathrm{P}$ acquisition efficiency rather than $\mathrm{P}$ use efficiency. This hypothesis is reasonable, because one would expect that use patterns of an essential, yet scarce, resource such as $\mathrm{P}$ would be determined by metabolism and the basic life form of the plant and would therefore be relatively uniform within a cultivated species. In contrast, variation in the ability to acquire $\mathrm{P}$ in the first place may be more pronounced because of ancestral adaptation to diverse edaphic regimes, compounded by more recent breeding and selection under high-fertility conditions. Reports of intraspecific differences in $\mathrm{P}$ acquisition efficiency date back to 1934 (Smith, 1934). Possible mechanisms of P acquisition efficiency include:
Root exudates, such as phosphatases, organic acids, and protons can liberate inorganic $\mathrm{P}$ from bound $\mathrm{P}$ pools (especially organic $\mathrm{P}, \mathrm{Fe}-\mathrm{P}$ compounds, and $\mathrm{Al}-\mathrm{P}$ compounds) that predominate in most tropical soils (Marschner, 1987; Uren and Reisenauer, 1988). Beans exude phosphatases into the rhizosphere (Helal, 1990), and other legumes, such as pigeon pea [Cayanus cajan (L.) Huth], release organic acids into the rhizosphere that liberate $\mathrm{P}$ by complexing Fe ligands (Ae et al., 1990). To determine whether variation in root exudates accounted for genetic differences in $\mathrm{P}$ efficiency in bean germplasm, we compared the performance of a set of contrasting genotypes on natural and artificial soils in which $\mathrm{P}$ was available mainly as organic or various inorganic complexes (Yan, 1992). Although some genotypes were capable of extracting more P from calcium phosphates in an artificial medium, in most tropical soils, the calcium-bound fraction is insignificant. There was no evidence that any superior genotypes were capable of extracting $\mathrm{P}$ from unavailable $\mathrm{P}$ pools (organic, iron, or aluminum phosphates) normally found in tropical soils. This finding argues against a role for exudates in accounting for existing genetic variation for $\mathrm{P}$ efficiency. We have observed genetic variation for acid phosphatase activity in leaves and roots, but such variation appears to be more related to the severity of $\mathrm{P}$ deficiency in the tissues of a given genotype rather than superior $\mathrm{P}$ adaptation (CIAT, 1986; McLachlan, 1980; Yan, 1992).

Mycorrhizal symbiosis between certain fungi and the roots of most higher plants is very important for $\mathrm{P}$ acquisition (Abbott and Robson, 1982; Bolan 1991; Koide, 1991). Beans are moderately mycotrophic in that they respond to mycorrhizal infection but are capable of growing fairly well without the fungal symbiont (Lynch et al., 1991). Our field observations of the mycorrhizal colonization of bean roots showed that they are uniformly highly infected, with from $60 \%$ to $80 \%$ of the root length containing fungal symbionts, regardless of $\mathrm{P}$ treatment or genotype (Yan, 1992). In fact, in a replicated trial designed specifically to look for genetic variation in mycorrhizal colonization of bean roots ( 25 bean genotypes by three fungal species with a sterilized control), we were unable to conclude anything because all treatments, including the sterilized control plants, were highly colonized. Genetic rankings of P efficiency in field environments and artificial substrates in greenhouse environments are similar (Yan, 1992), indicating that the presence or absence of fungal inoculum does not account for existing genetic variation for $\mathrm{P}$ efficiency.

Root activity and architecture are especially important for $\mathrm{P}$ acquisition because the relative immobility of $\mathrm{P}$ in soil makes $\mathrm{P}$ acquisition by the plant very dependent on efficient soil exploration in time and space (Barber, 1984). We have observed

Table 2. Simulation model of $\mathrm{C}$ balance in beans, based on data for leaf photosynthesis and biomass allocation (Lynch et al., 1991), and published values for tissue respiration. The model simulated growth of bean cultivar EMP 84 over 34 days and predicted plant dry weight and leaf area accurately. Estimated $\mathrm{C}$ retention, calculated as total $\mathrm{C}$ retained divided by total C fixed, was strongly reduced by P stress (J. Lynch, A. Läuchli, and E. Epstein, unpublished data).

\begin{tabular}{lcc}
\hline \hline P level and & \multicolumn{2}{c}{ Data } \\
\cline { 2 - 3 } criterion & Observed & Model \\
\hline Low & 1.1 & 1.1 \\
$\quad$ Dry weight $(\mathrm{g})$ & 83 & 83 \\
Leaf area $\left(\mathrm{cm}^{2}\right)$ & --- & 0.26 \\
$\quad$ retention & 8.2 & 8.6 \\
Medium & 950 & 875 \\
$\quad$ Dry weight & --- & 0.55 \\
Leaf area & & \\
C retention & 20.5 & 20.7 \\
High & 2889 & 2270 \\
Dry weight & --- & 0.62 \\
Leaf area & & \\
C retention & & \\
\hline
\end{tabular}


substantial genetic variation in the growth and architecture of bean root systems, with preliminary evidence that P-efficient genotypes have a vigorous, highly branched root system with many growing points (Lynch and van Beem, 1993). Indeed, various theoretical and empirical lines of evidence indicate that root architecture (the three-dimensional shape of the root system over time) may be the basis for genetic differences in $\mathrm{P}$ efficiency in beans, as discussed below.

\section{High P}

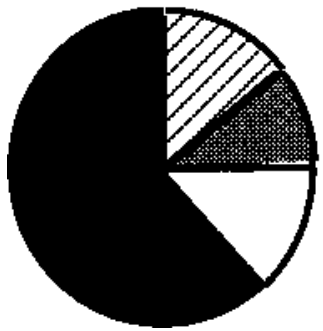

Low P

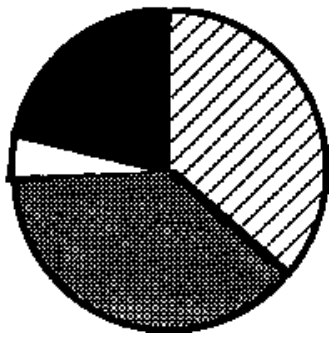

Fig. 1. Diurnal $\mathrm{C}$ budget in beans at anthesis as percentage of daytime net $\mathrm{C}$ fixation. Striped = daytime root $\mathrm{C}$ respiration, gray = nighttime root $\mathrm{C}$ respiration; white $=$ nighttime shoot $\mathrm{C}$ respiration; black = daytime shoot C fixation not lost to respiration. Data confirm model predictions that root $\mathrm{C}$ costs are important to $\mathrm{P}$-stressed beans. We believe that root $\mathrm{C}$ costs in $\mathrm{P}$-stressed plants account for low $\mathrm{C}$ retention (Table 2).

\section{Importance of root growth and architecture in $P$ efficiency}

A useful way to consider the physiological efficiency of a process, such as $\mathrm{P}$ acquisition, is to employ an economic analogy, where $\mathrm{P}$ acquisition is the "benefit" derived by plant "costs" associated with root construction, etc. (Bloom et al., 1985). One standard "currency" used by plant scientists to compare the costs and benefits of a process or adaptation is $\mathrm{C}$, as $\mathrm{C}$ is a primary constituent of plant dry matter and is intimately involved in plant metabolism (Reekie and Bazzaz, 1987). Applying this economic paradigm of plant function to the problem of $\mathrm{P}$ acquisition efficiency, we can analyze the physiological efficiency of root systems by comparing the C costs of root construction, maintenance, and activities with the benefit of $\mathrm{P}$ acquired by the root system from the environment. We operationally define the relationship of $\mathrm{P}$ acquisition and below-ground $\mathrm{C}$ expenditure (which will be dynamic rather than a simple ratio) as phosphorus acquisition efficiency, or PAE.

Evidence from modeling, in conjunction with data from growth analysis and partitioning studies, has shown that root system C costs may limit plant growth under low-fertility conditions (Fredeen et al., 1989; Lynch et al., 1991). For example, a simple simulation model of $\mathrm{C}$ economy using data from a study we recently conducted on bean growth under variable $\mathrm{P}$ conditions (Lynch et al., 1991) indicates that biomass gain per unit leaf area is low under P deficiency because each unit of leaf area has a greater burden of heterotrophic tissue (primarily the root system) to sustain, not because photosynthesis was impaired (Table 2). In fact, the model predicts that P-stressed plants only retain
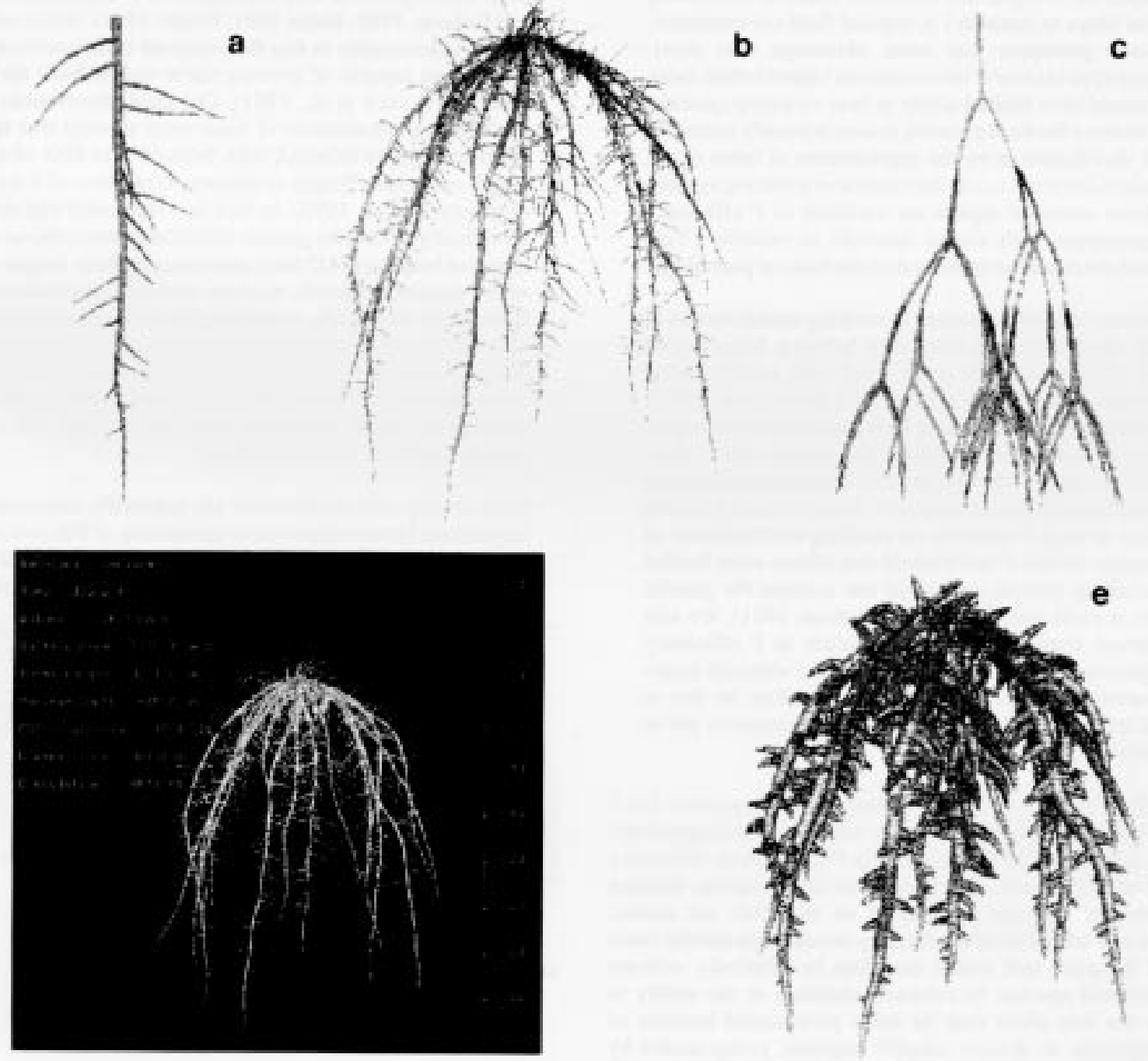

Fig. 2. Geometric simulation of bean root growth with the SimRoot model (a) herringbone root architecture, (b) Phaseolus vulgaris L. cv. Carioca root system, (c) dichotomous root architecture, (d) mature seedling root of 'Carioca', (e) P depletion zones (roots not shown) around 'Carioca' root system. Configuration of the 'Carioca' root system was derived from observations of soil-grown plants in the tropics, whereas the configurations of the herringbone and dichotomous architectures are synthetic topological extremes. Phosphorus depletion zones were estimated from the diffusion rate of P in well-watered soil. 
(a)

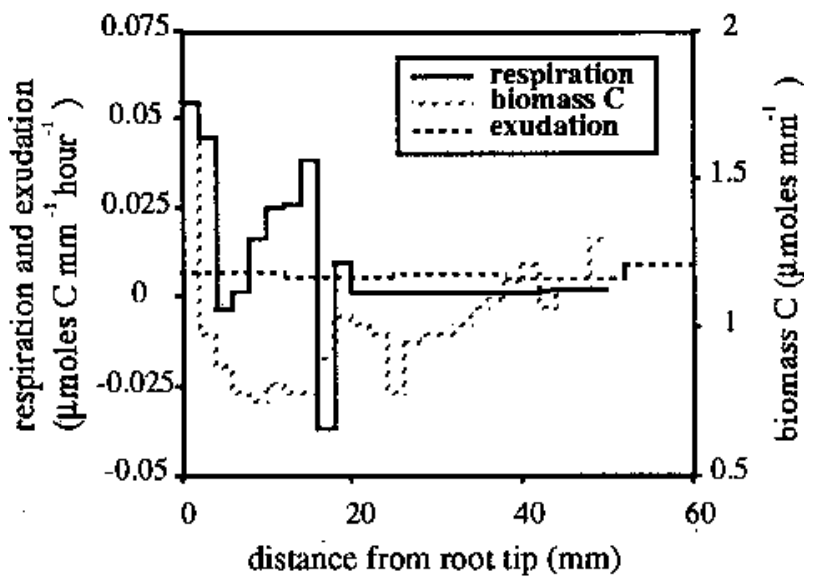

(b)

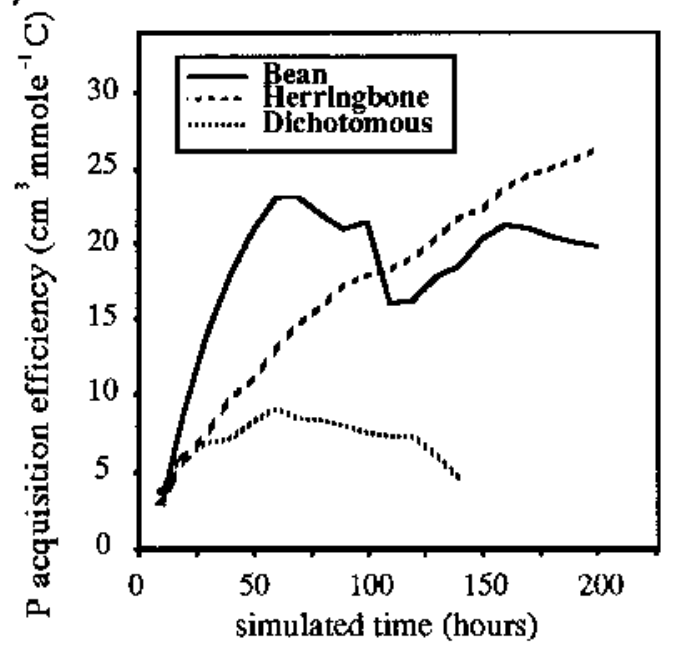

(c)

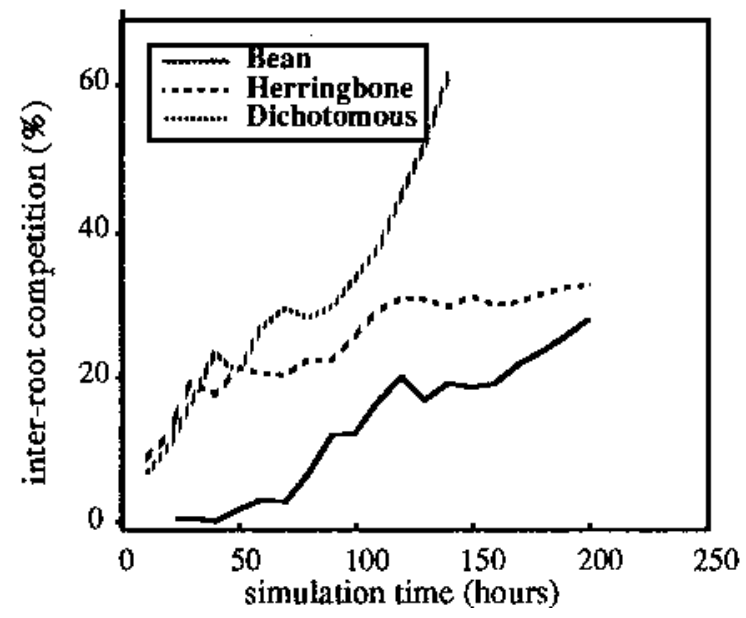

Fig. 3. (a) Carbon cost distribution along root axes of bean cultivar G4000, (b) $\mathrm{P}$ acquisition efficiency over time for contrasting root architectures (as shown in Fig. 2) as simulated by SimRoot, (c) intraroot competition over time for contrasting root architectures (as shown in Fig. 2) as simulated by SimRoot. Using the $\mathrm{C}$ cost information shown in Fig. 3a and $\mathrm{P}$ acquisition information as shown in Fig. 2e, integrated phosphorus acquisition efficiency (PAE) was estimated over time for each of the architectures shown in Fig. 2a-c. Figure $3 \mathrm{~b}$ indicates that the contrasting root architectures do have different PAE. Figure $3 \mathrm{c}$ shows that intraroot competition (overlap of $\mathrm{P}$ depletion zones) may account for differences in PAE in the contrasting root architectures. $\approx 25 \%$ of the $\mathrm{C}$ they acquire through photosynthesis, in contrast to $75 \%$ retained in high-P plants. Experimental measurements of $\mathrm{C}$ budgets in $P$ stressed beans confirm these model predictions (Fig. 1). Because root growth is important for $\mathrm{P}$ acquisition, yet $\mathrm{C}$ consumption by roots is a primary constraint to the growth of P-stressed plants, it is reasonable to assume that genotypes with root systems that use less $\mathrm{C}$ in acquiring $\mathrm{P}$ or that acquire more $\mathrm{P}$ per unit $\mathrm{C}$ used will have superior performance in low-P soils.

Although root architecture (the three-dimensional configuration of a root system) determines soil exploration in time and space and should, therefore, influence PAE, this relationship has been studied little and is poorly understood, primarily because of the difficulty in conceptualizing and analyzing root architecture. Fitter and colleagues (Fitter, 1991; Fitter et al., 1991) suggested that, on the basis of abstract models of root topology in two and three dimensions, root architecture should influence PAE. We developed an explicit geometric model of root growth in time and space (SimRoot) that includes empirical data for the spatial distribution of $\mathrm{C}$ respiration, exudation, and biomass deposition along bean root axes to demonstrate that contrasting root architectures are likely to have different PAE (Figs. 2 and 3; Davis, 1993; Nielsen et al., 1994). Architectural effects of PAE were related to the different proportions of growing and mature root tissue in contrasting architectures, because $\mathrm{C}$-use profiles were dynamic along root axes, and varying degrees of spatial competition between adjacent roots within a root system. The specific architectural traits that may contribute to the PAE of bean root systems are being investigated through continued modeling coupled with measuring $\mathrm{C}$ and $\mathrm{P}$ budgets in contrasting bean genotypes.

\section{Plasticity and $P$ acquisition efficiency}

Another root trait that may be important for $\mathrm{P}$ efficiency is plasticity, or the ability to sense and respond to localized or temporary changes in $\mathrm{P}$ availability [for a general discussion, see Grime et al. (1991) and references therein]. It has been known for some time that roots proliferate in zones of high $\mathrm{P}$ availability (e.g., Drew and Saker, 1978). According to Snapp and Lynch (1993), global and local responses of bean root systems to $\mathrm{P}$ stress permit greater exploitation of a P-rich zone at reduced biomass cost, suggesting that plasticity indeed enhances PAE (Table 3). We also have recently observed stimulation of root branching in response to low $\mathrm{P}$ availability in the immediate root environment (Fig. 4). Bean genotypes contrast in their degree of root plasticity in response to $P$ stress (Fig. 4). Bean roots also may change their geotropic curvature in response to low $P$ availability, thereby changing the total volume of soil explored by the umbrella of basal roots (basal roots are the main lateral branches from the taproot in a dicot seedling), as well as the proportion of the root system in the topsoil, where P availability is typically higher than in the subsoil (Fig. 5). Genetic variation also has been observed for $P$ stress $\times$ gravitropism interaction (Table 4). This sort of selective exploitation of specific soil microenvironments could contribute significantly to root system efficiency by allocating $\mathrm{C}$ expenditures to portions of the environment with greatest $P$ availability.

Table 3. Estimates of costs associated with investment of roots in a patch of $\mathrm{P}$ enriched soil by low-P and high-P plants. Roots were divided up into fine and thick roots, and the percentage contribution of fine roots to cost estimates is reported. Low-P plants were able to exploit a patch of $\mathrm{P}$, as evidenced by root length in the patch, with comparatively less investment in biomass and root $\mathrm{P}$ by increasing the proportion of fine to thick roots. Means (and standard deviations in parentheses) are presented from five replications. (S. Snapp, R. Koide, and J. Lynch, unpublished data).

\begin{tabular}{lccccc}
\hline \multirow{2}{*}{$\begin{array}{l}\text { Investment in } \\
\text { P-patch }\end{array}$} & \multicolumn{2}{c}{ Low P } & & \multicolumn{2}{c}{ High P } \\
\cline { 2 - 3 } \cline { 5 - 6 } & Plants & Fine roots (\%) & Plants & Fine roots (\%) \\
\hline Root length (m) & $1.4(0.7)$ & 97 & & $1.7(0.4)$ & 96 \\
Biomass (mg) & $30(11)$ & 70 & & $65(16)$ & 58 \\
Phosphorus (mg) & $0.06(0.02)$ & 88 & & $0.11(0.03)$ & 73 \\
\hline
\end{tabular}




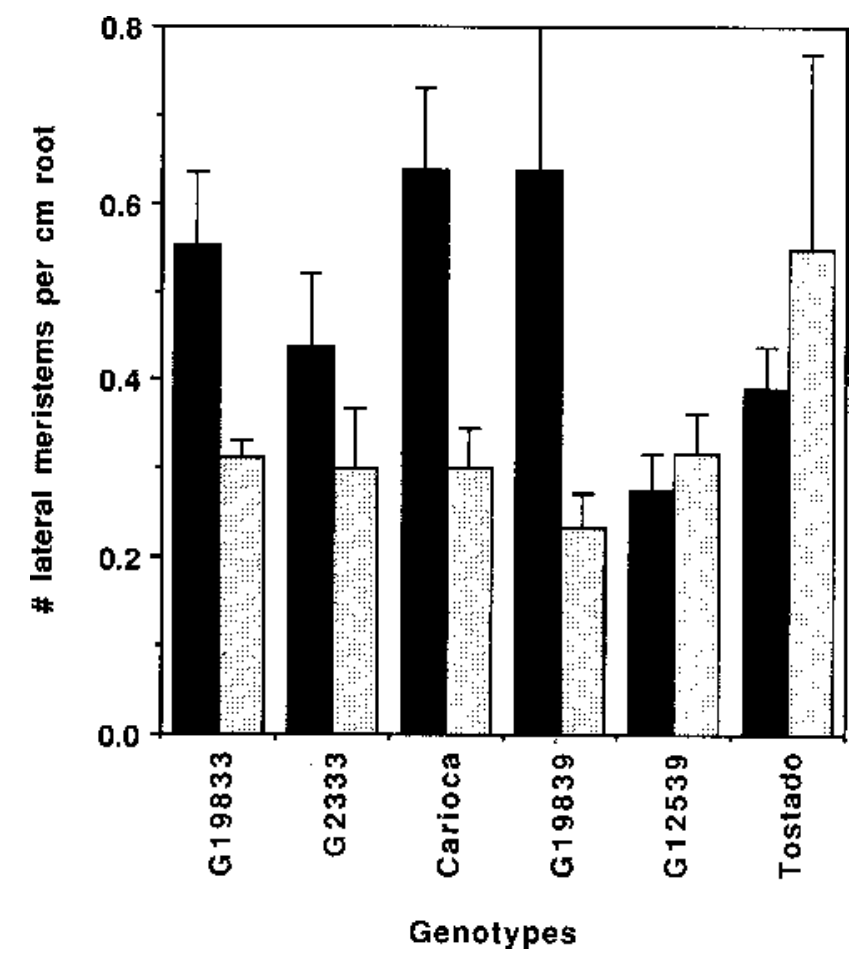

Fig. 4. Stimulation of lateral branching in P-deficient bean genotypes. Plants were grown 9 days in pouches supplied with $1 \mathrm{~mm} P$ (dotted bars) or without $\mathrm{P}$ (black bars). Each bar is the mean of five replications, with SE. Effects of $\mathrm{P}$ supply, genotype, and $\mathrm{P} \times$ genotype interaction were significant at $P=$ 0.001 .

A

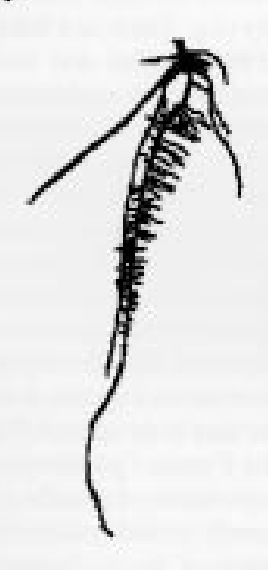

Fig. 5. Effect of $P$ stress on geotropic curvature in basal roots of bean seedlings grown 5 days in nutrient solution (a) with $1 \mathrm{~mm} \mathrm{P},(\mathbf{b})$ without $\mathrm{P}$.

\section{Prospects}

On the basis of the theoretical and empirical evidence noted above, we hypothesize that genetic differences for P efficiency in bean germplasm are caused primarily by genetic variation for root traits. Root biology is a poorly understood and methodologically challenging area in plant science, and to investigate this hypothesis in bean germplasm, we must address several conceptual and methodological issues of more general relevance. Methodologically, we must develop tools to analyze, quantify, and summarize root activity in time and space. Conceptually, we must develop ways to think about the interrelation of root topology (two-dimensional branching structure), architecture (three-dimensional configuration of the root system), and plasticity in a functional context that permits the validation of specific hypotheses concerning the impact of root traits on plant fitness (which might be expressed as yield in an agricultural context). We believe that
Table 4. Branching angle of basal roots of bean seedlings as affected by $\mathrm{P}$ availability. Angles from horizontal of root tips grown in pouches were measured 7 days after germination ( 5 days after emergence) with either 0 or $1 \mathrm{~mm} P$ in the nutrient solution. Low external $\mathrm{P}$ availability increased the branching angle in some genotypes and decreased it or had no effect in others. Each value is the mean of three or four replicate plants with five to 10 basal roots per plant, followed by the standard error.

\begin{tabular}{lccc}
\hline \hline & \multicolumn{3}{c}{ Branching angle from horizontal $\left(^{\circ}\right)$} \\
\cline { 2 - 4 } Genotype & $+\mathrm{P}$ & $-\mathrm{P}$ & $\begin{array}{c}\mathrm{F}(P \text { effect }) \\
\text { from ANOVA }\end{array}$ \\
\hline G19839 & $51.5(5.4)$ & $39.8(5.3)$ & 3.140 \\
BAT1224 & $53.4(3.8)$ & $41.8(3.4)$ & 3.031 \\
G19833 & $72.1(3.0)$ & $57.9(3.1)$ & $6.271^{*}$ \\
G12539 & $66.6(3.4)$ & $55.2(3.5)$ & $8.388^{* *}$ \\
DOR364 & $61.8(5.0)$ & $53.8(5.4)$ & 0.489 \\
Carioca & $65.2(7.1)$ & $58.6(6.9)$ & 0.530 \\
G2333 & $59.5(5.0)$ & $69.5(7.0)$ & $4.593^{*}$ \\
\hline
\end{tabular}

*,**Significant at $P \leq 0.05$ or 0.01 , respectively. Analysis of variance (ANOVA) indicated the effect of genotype $(\mathrm{F}=4.483, P \leq 0.001)$ and the interaction of genotype and time $(\mathrm{F}=6.763, P \leq 0.001)$ had significant effects on root branching angle (from Bonser et al., 1994).

simulation modeling of root architecture will be one useful approach, since the architecture of actual root systems is so complex and difficult to quantify (Wullshleger et al., 1994). Carbon budgeting also may be useful as a means of quantifying the physiological efficiency of contrasting root systems. Fractal geometry may provide useful perspectives for the analysis and measurement of root architecture (Bernston et al., 1995; Nielsen and Lynch, 1994). As more information becomes available concerning the genetic basis of root traits, direct genetic manipulation will permit rigorous evaluation of hypotheses concerning root form and function.

We believe there is great potential for the development of Pefficient bean cultivars. Realizing this potential will require a multidisciplinary effort involving plant breeders, physiologists, and molecular biologists working together to characterize, understand, and manipulate bean genetic resources.

\section{Literature Cited}

Abbott, L.K. and A.D. Robson. 1982. The role of vesicular-arbuscular mycorrhizal fungi in agriculture and the selection of fungi for inoculation. Austral. J. Agr. Res. 33:389-408.

Ae, N., J. Arihara, K. Okada, T. Yoshihara, and C. Johansen. 1990. Phosphorus uptake by pigeon pea and its role in cropping systems of the Indian subcontinent. Science 248:477-480.

Barber, S.A. 1984. Soil nutrient bioavailability, A mechanistic approach. Wiley, New York.

Bernston, G.M., J.P. Lynch, and S. Snapp. 1995. Fractal geometry and plant root systems: Current perspectives and future applications. In: P. Baveye, J.Y. Parlange, and B.A. Stewart (eds.). Fractals in soil science. Lewis Publishers, New York.

Bloom, A.J., F.S. Chapin, and H.A. Mooney. 1985. Resource allocation in plants: An economic analogy. Annu. Rev. Ecol. Systematics 16:363-392.

Boerma, H.R. and R.L. Cooper. 1975. Effectiveness of early generation yield selection of heterogeneous lines in soybeans. Crop Sci. 15:313-315.

Bolan, N.S. 1991. A critical review on the role of mycorrhizal fungi in the uptake of phosphorus by plants. Plant \& Soil 134:189-207.

Bonser, A.B., J.P. Lynch, and S. Snapp. 1994. Differences in gravitropic response and branching angle in response to phosphorus stress in genotypes of Phaseolus vulgaris. Plant Physiol. 105:95. (Abstr.)

Cathcart, J.B. 1980. World phosphate reserves and resources, p. 1-18. In: F.E. Khasawneh, E.C. Sample, and E.J. Kamprath (eds.). The role of phosphorus in agriculture. Amer. Soc. Agron., Madison, Wis.

Clark, R.B. 1990. Physiology of cereals for mineral nutrient uptake, use, and efficiency, p. 131-210. In: V.C. Baligar and R.R. Duncan (eds.). Crops as enhancers of nutrient use. Academic, New York.

Davis, R.D. 1993. Modeling and visualization of botanical root systems. MS Thesis, Pennsylvania State Univ., University Park.

Drew, M.C. and L.R. Saker. 1978. Nutrient supply and the growth of the seminal root system in barley. III. Compensatory increase in growth of lateral roots, and in rates of phosphate uptake, in response to a localized supply of phosphate. J. Expt. Bot. 29:435-451.

Epstein, E. 1972. Mineral nutrition of plants: Principles and perspectives. Wiley, New York. 
Fawole, I., W.H. Gabelman, and G.C. Gerloff. 1982b. Genetic control of root development in beans (Phaseolus vulgaris L.) grown under phosphorus stress. J. Amer. Soc. Hort. Sci. 107:98-100.

Fawole, I., W.H. Gabelman, G.C. Gerloff, and E.V. Nordheim. 1982a. Heritability of efficiency in phosphorus utilization in beans (Phaseolus vulgaris L.) grown under phosphorus stress. J. Amer. Soc. Hort. Sci. 107:94-97.

Fitter, A.H. 1991. Characteristics and functions of root systems, p. 3-24. In: Y. Waisel, A. Eshel, and U. Kafkafi (eds.). Plant roots, The hidden half. Marcel Dekker, New York.

Fitter, A.H., T.R. Stickland, M.L. Harvey, and G.W. Wilson. 1991. Architectural analysis of plant root systems. I. Architectural correlates of exploitation efficiency. New Phytol. 118:375-382.

Fredeen, A.L., I.M. Rao, and N. Terry. 1989. Influence of phosphorus nutrition on growth and carbon partitioning in Glycine max. Plant Physiol. 89:225230.

Grime, J.P., B.D. Campbell, J.M.L. Mackey, and J.C. Crick. 1991. Root plasticity, nitrogen capture and competitive ability, p. 381-397. In: D Atkinson (ed.). Plant root growth: An ecological perspective. Blackwell, London.

Helal, H.M. 1990. Varietal differences in root phosphatase activity as related to the utilization of organic phosphates. Plant \& Soil 123:161-163.

International Center for Tropical Agriculture (CIAT). 1986. Bean program annual report. CIAT, Cali, Colombia.

Janssen, W., S. Teixeira, and M. Thung. 1992. Adocao de cultivares melhorados de feijao em estados selecionados no Brasil. Revista Economica e Sociologia Rural 30(4):321-333.

Koide, R.T. 1991. Nutrient supply, nutrient demand, and plant response to mycorrhizal infection. New Phytol. 117:365-386.

Lynch, J., A. Läuchli, and E. Epstein. 1991. Vegetative growth of the common bean in response to $\mathrm{P}$ nutrition. Crop Sci. 31:380-387.

Lynch, J. and J. van Beem. 1993. Growth and architecture of seedling roots of common bean genotypes. Crop Sci. 33:1253-1257.

Marschner, H. 1987. Mineral nutrition of higher plants. Academic, New York.

Martin, G.B., J.G.K. Williams, and S.D. Tanksley. 1991. Rapid identification of markers linked to a pseudomonas resistance gene in tomato by using random primers and near-isogenic lines. Proc. Natl. Acad. Sci. USA 88:2336-2340.

McLachlan, K.D. 1980. Acid phosphatase activity of intact roots and phosphorus nutrition in plants. II. Variation among wheat roots. Austral. J. Agr. Res. 31:441-448.

Michelmore, R.W., I. Paran, and R.V. Kessell. 1991. Identification of markers linked to disease resistance genes by bulked segregant analysis: A rapid method to detect markers in specific genomic regions using segregating populations. Proc. Natl. Acad. Sci. USA 88:9828-9832.

Miklas, P.N., S.R. Stavely, and J.O. Kelley. 1993. Identification and potential use of a molecular marker for rust resistance in common bean. Theor. Appl. Genet. 85:649-652.

Netzer, W. 1987. Phosphate solubilizing genes might revolutionize fertilizer technology. Gen. Eng. News 7:10, 41.

Nielsen, K.L., J.P. Lynch, A.G. Jablokow, and P.S. Curtis. 1994. Carbon cost of root systems: An architectural approach. Plant \& Soil 165:161-169.

Nielsen, K.N. and J.P. Lynch. 1994. Fractal analysis of bean root systems. Agron. Abstr.

Paran, I. and R.W. Michelmore. 1992. Development of reliable PCR-based markers linked to downy-mildew resistance genes in lettuce. Theor. Appl. Genet. 85:985-993.

Reekie, E.G. and F.A. Bazzaz. 1987. Reproductive effort in plants. 2. Does carbon reflect the allocation of other resources? Amer. Naturalist 129:897-906.
Rendig, V.V. and H.M. Taylor. 1989. Principles of soil-plant relationships. McGraw-Hill, New York.

Sadeghian, S. 1991. Influencia de algunas caracteristicas de las semillas y plantulas de frijol (Phaseolus vulgaris L.) sobre la tolerancia a la baja disponibilidad de fosforo en el suelo. MS Thesis, National Univ. of Colombia, Palmira.

Salinas, J.G. 1978. Differential response of some cereal and bean cultivars to $\mathrm{Al}$ and $\mathrm{P}$ stress in an oxisol of central Brasil. PhD Diss., Raleigh, North Carolina State Univ., Raleigh.

Sample, E.C., R.J. Soper, and G.J. Racz. 1980. Reactions of phosphate fertilizers in soils, p. 263-310. In: F.E. Khasawneh, E.C. Sample, and E.J. Kamprath (eds.). The role of phosphorus in agriculture. Amer. Soc. Agron., Madison, Wis.

Schettini, T.M., W.H. Gabelman, and G.C. Gerloff. 1987. Incorporating of phosphorus efficiency from exotic germplasm into agriculturally adapted germplasm of common bean (Phaseolus vulgaris L.). Plant \& Soil 99:175184.

Singh, S.P.,P. Gepts, and D. Debouck. 1991. Races of common bean (Phaseolus vulgaris, Fabacea). Econ. Bot. 45(3):379-396.

Singh, S.P., C.A. Urrea, J.A. Gutierrez, and J. Garcia. 1989. Selection for yield at two fertilizer levels in small seeded common bean. Can. J. Plant Sci. 69:1011-1017.

Smith, S.N. 1934. Response of inbred lines and crosses in maize to variations of nitrogen and phosphorus supplied as nutrients. J. Amer. Soc. Agron. 26:785-804.

Snapp, S. and J. Lynch. 1993. Main versus external roots and phosphorus efficiency in common bean: Are all roots created equal? HortScience 28:126. (Abstr.)

Stevenson, F.J. 1986. Cycles of soil. Carbon, nitrogen, phosphorus, sulfur, micronutrients. Wiley, New York.

Tanksley, S.D., N.O. Young, A.H. Paterson, and M.W. Bonierbale. 1989. RFLP mapping in plant breeding: New tools for an old science. Bio/Technology 7:257-264.

Tapia, B.H. 1987. Variedades mejoradas de frijol Phaseolus vulgaris L. con grano rojo para Nicaragua. Instituto Superior de Ciencias Agropecuarias. Dirección de Investigación y Postgrado, Managua, Nicaragua.

Thung, M. 1990. Phosphorus: A limiting nutrient in bean (Phaseolus vulgaris L.) production in Latin America and field screening for efficiency and response, p. 501-521. In: N. El Bassam, M. Dambroth, and B.C. Loughman (eds). Genetic aspects of plant mineral nutrition. Kluwer Academic Publishers, The Netherlands.

Uren, N.C. and H.M. Reisenauer. 1988. The role of root exudation in nutrient acquisition. Adv. Plant Nutr. 3:79-114.

Whiteaker, G., G.C. Gerloff, W.H. Gabelman, and D. Lindgren. 1976. Intraspecific differences in growth of beans at stress levels of phosphorus. J. Amer. Soc. Hort. Sci. 101:472-475.

Williams, J.G.K. and A.R. Kubelik. 1990. DNA polymorphisms amplified by arbitrary primers are useful as genetic markers. Nucleic Acids Res. 12:65316535.

Wullschleger, S.D., J.P. Lynch, and G.M. Berntson. 1994. Modeling the below ground response of plants and soil biota to edaphic and climatic changeWhat can we expect to gain? Plant \& Soil 165:149-160.

Yan, X. 1992. Characterization of common bean (Phaseolus vulgaris L.) germplasm for tolerance of low phosphorus availability in tropical soils. PhD Diss., South China Agricultural Univ., Pennsylvania State Univ., International Center for Tropical Agriculture.

Youngdahl, L.J. 1990. Differences in phosphorus efficiency in bean genotypes. J. Plant Nutr. 13:1381-1392. 